Article

\title{
Development of a Highly Sensitive FcMito qPCR Assay for the Quantification of the Toxigenic Fungal Plant Pathogen Fusarium culmorum
}

\author{
Katarzyna Bilska ${ }^{1, *(\mathbb{D})}$, Tomasz Kulik ${ }^{1}{ }^{(\mathbb{D})}$, Anna Ostrowska-Kołodziejczak ${ }^{2}$, Maciej Buśko ${ }^{2}$, \\ Matias Pasquali ${ }^{3}$ (D), Marco Beyer ${ }^{4}$, Anna Baturo-Cieśniewska ${ }^{5}$, Marcin Juda ${ }^{5}$, \\ Dariusz Załuski ${ }^{6}{ }^{(1)}$, Kinga Treder ${ }^{7}$, Joerg Denekas ${ }^{8}$ and Juliusz Perkowski ${ }^{2}$ \\ 1 Department of Microbiology and Mycology, University of Warmia and Mazury in Olsztyn, \\ Oczapowskiego 1A, 10-719 Olsztyn, Poland; tomaszkulik76@gmail.com \\ 2 Department of Chemistry, Poznań University of Life Sciences, Wojska Polskiego 75, 60-625 Poznań, Poland; \\ ostrowska.anna.maria@gmail.com (A.O.-K.); mabu@up.poznan.pl (M.B.); julperk@up.poznan.pl (J.P.) \\ 3 Department of Food, Environmental and Nutritional Sciences (DEFENS), University of Milan, via Celoria 2, \\ 20133 Milano, Italy; matias.pasquali@unimi.it \\ 4 Department Environmental Research and Innovation, Luxembourg Institute of Science and Technology, 41, \\ rue du Brill, L-4422 Belvaux, Luxembourg; marco.beyer@list.lu \\ 5 Faculty of Agriculture and Biotechnology, Department of Phytopathology and Molecular Mycology, \\ University of Technology and Life Sciences, Kordeckiego St. 20, 85-225 Bydgoszcz, Poland; \\ baturo-a@utp.edu.pl (A.B.-C.); mar.bydg@gmail.com (M.J.) \\ 6 Department of Plant Breeding and Seed Production, University of Warmia and Mazury in Olsztyn, \\ Plac Łódzki 3, 10-727 Olsztyn, Poland; dariusz.zaluski@uwm.edu.pl \\ 7 Department of Agroecosystems, University of Warmia and Mazury in Olsztyn, Plac Łódzki 3, \\ 10-727 Olsztyn, Poland; kinga.treder@uwm.edu.pl \\ 8 Agravis Technik Heide-Altmark GmbH, Hansestrasse 30, 29525 Uelzen, Germany; \\ joergdenekas@googlemail.com \\ * Correspondence: katarzyna.bilska@uwm.edu.pl
}

Received: 26 April 2018; Accepted: 18 May 2018; Published: 21 May 2018

\begin{abstract}
Fusarium culmorum is a ubiquitous, soil-borne fungus (ascomycete) causing foot and root rot and Fusarium head blight on cereals. It is responsible for yield and quality losses as well as grain contamination with mycotoxins, which are a potential health hazard. An extremely sensitive mitochondrial-based qPCR assay (FcMito qPCR) for quantification of F. culmorum was developed in this study. To provide specificity, the FcMito assay was successfully validated against 85 F. culmorum strains and 53 isolates of 30 other fungal species. The assay efficiency and sensitivity were evaluated against different F. culmorum strains with various amounts of pure fungal DNA and in the presence of background wheat DNA. The results demonstrated the high efficiency of the assay (97.2-106.0\%, $\mathrm{R}^{2}$-values $>0.99$ ). It was also shown that, in the presence of background DNA, $0.01 \mathrm{pg}$ of fungal template could be reliably quantified. The FcMito assay was used to quantify F. culmorum DNA using 108 grain samples with different trichothecene levels. A significant positive correlation was found between fungal DNA quantity and the total trichothecene content. The obtained results showed that the sensitivity of the FcMito assay was much higher than the nuclear-based qPCR assay for F. culmorum.
\end{abstract}

Keywords: Fusarium culmorum; qPCR assay; quantification; detection; mitochondrial DNA (mtDNA); Fusarium head blight (FHB)

Key Contribution: A highly sensitive mitochondrial-based qPCR assay (FcMito qPCR) for the quantification of F. culmorum was developed in this study. 


\section{Introduction}

A common soil-borne fungus, Fusarium culmorum, remains an important cereal pathogen of a wide range of small-grain cereals, as well as maize [1,2]. On wheat and barley, it causes two distinct diseases: FRR (Fusarium foot and root rot) and FHB (Fusarium head blight), also known as ear blight or scab [1]. Both diseases cause significant yield losses and the latter results in contamination of the grain with trichothecenes, which may pose a grave threat to both food and feed safety [3-6]. Trichothecenes produced by F. culmorum include deoxynivalenol (DON), nivalenol (NIV), and their acetylated derivatives, 3-acetylodeoxynivalenol (3ADON) and 4-acetylnivalenol (4ANIV, syn. fusarenon X) [7], which differ in toxicity to mammals and plants [8]. Options of chemical control are very limited. F. culmorum can be controlled by fungicides containing triazoles as active ingredients, while strobilurins such as trifloxystrobin and succinate dehydrogenase inhibitors such as isopyrazam are hardly effective [9].

Before 2000, F. culmorum was the predominant agent of FHB in Northern, Central, and Western Europe $[1,10]$. However, since that time, a change has been observed in many European countries in the distribution of F. culmorum, which appears to be replaced by F. graminearum sensu stricto (s.s.) [11]. This progressive switch may be explained by the increased production of maize, which favors the production of ascospores by F. graminearum s.s. Other causes of F. culmorum to F. graminearum s.s. replacement may be related to the gradual adaptation of $F$. graminearum s.s. to colder climates $[12,13]$ or to the recorded rise in average temperatures caused by climate change [1,14-16]. It is, however, noteworthy that F. culmorum can predominate in certain European locations. For example, in Luxembourg, following the dry year 2011, F. culmorum was identified from the majority of symptomatic wheat heads, whereas only $10 \%$ were infected by F. graminearum s.s. [17]. F. culmorum is now frequently reported as the main agent of FRR and FHB in the Mediterranean region, which is contrary to surveys from Central and Northern Europe [1,18-25].

Traditionally, identification of F. culmorum is based on the shape of the macroconidia formed in sporodochia $[1,26]$. However, morphological identification of Fusaria is time-consuming, requires qualified experts in the field of culturing fungi [27], and precludes the distinction of species frequently occurring on wheat [26]. In addition, ascomycetes cannot be reliably quantified by the viable count procedures $[28,29]$. Recently, quantitative polymerase chain reaction (qPCR) has been found to be a most promising method for fungal quantification from different environmental samples. qPCR offers several advantages over other diagnostic techniques, including higher sensitivity and specificity and a rapid turnaround time. At least four specific real-time PCR assays have previously been designed for F. culmorum, using either SybrGreen or TaqMan chemistries [30-33]. However, fungal quantification is sometimes a challenge, mostly due to the relatively low fungal biomass in environmental samples and the fungal cell wall structure itself, which makes nucleic acid extraction difficult [34]. The sensitivity of qPCR assays can be improved with diagnostic assays focusing on various multi-copy DNA regions, such as mitochondrial DNA (mtDNA). As was successfully demonstrated with the development of the FgMito assay for quantification of $F$. graminearum s.s. [35].

The present study sought to design a highly sensitive FcMito qPCR assay to quantify F. culmorum. To ensure high assay sensitivity, primers and a minor-groove binding (MGB) probe were prepared based on multi-copy mitochondrial DNA. The specificity of the assay was evaluated against both a broad range of F. culmorum strains from distinct localities as well as other Fusarium species. The assay's efficiency and sensitivity were further evaluated against a test panel of different F. culmorum strains with various amounts of pure fungal DNA as well as in the presence of wheat background DNA. F. culmorum was quantified using the FcMito assay from 108 field samples with different trichothecene amounts. 


\section{Results}

2.1. The Design of a Primer/Probe Set for Specific Quantification of F. culmorum Based on the Mitochondrial COX2 Gene

To design a primer/probe set specific for F. culmorum, complete mitogenomes of F. culmorum, F. graminearum s.s., and F. gerlachii were aligned. An intron3 within the COX2 gene was present in F. culmorum only, based on which a primer/probe set was designed for specific quantification of this species. In silico specificity of primers and the designed probe was further confirmed by BLAST searches.

\subsection{Optimizing a TaqMan Assay Specific for F. culmorum}

The 138 Fusarium strains were used to evaluate the specificity of the FcMito assay (Table S1). All 85 F. culmorum strains emitted a fluorescent signal with the FcMito assay, whereas no amplification was noted on the remaining tested non-target Fusaria. The efficiency of the FcMito assay ranged from 98.5 to $100.5 \%$, while the coefficient of determination was greater than $\mathrm{R}^{2}=0.995$ (Table 1 ). No significant differences were recorded in the $C_{T}$ range, $R^{2}$, or efficiency between pure strain standards or standards mixed with $30 \mathrm{ng}$ of wheat background DNA. No false-positive signals were detected when using $30 \mathrm{ng}$ of wheat DNA (Table 2). Six low concentrations of F. culmorum DNA (2, 0.5, 0.2, 0.05, 0.02, and $0.01 \mathrm{pg}$ ) showed no false-negative results in the presence of background wheat DNA. A false-negative rate of $34.7 \%$ was found for the lowest DNA input $(0.005 \mathrm{pg})$. In this way, the limit of quantification (LOQ) of the FcMito assay could be established as $0.05 \mathrm{pg}$.

Table 1. Validation results of FcMito assay based on 10 PCR runs using pure strain standards and templates mixed with $30 \mathrm{ng}$ of wheat DNA.

\begin{tabular}{ccccc}
\hline Strain & $\begin{array}{c}\text { Assay Quantitative } \\
\text { Dynamic Range (pg) }\end{array}$ & C $_{\text {T }}$ Range & R $^{\mathbf{2}}$ & Efficiency (\%) \\
\hline M601 & $6840-0.68$ & $15.31 \pm 0.17-28.18 \pm 0.20$ & 0.998 & 99.2 \\
ZFc 0502 & $6500-0.65$ & $14.99 \pm 0.19-28.15 \pm 0.17$ & 0.998 & 99.9 \\
ZFc 0601 & $27,320-2.73$ & $12.72 \pm 0.18-25.98 \pm 0.16$ & 0.998 & 99.0 \\
ZFc 0601 ${ }^{b}$ & & $12.9 \pm 0.09-26.17 \pm 0.12$ & 0.999 & 98.9 \\
CBS 110568 & 8720-0.67 & $23.34 \pm 0.12-36.68 \pm 0.13$ & 0.998 & 99.7 \\
CBS 110568 ${ }^{\mathrm{b}}$ & & $22.98 \pm 0.14-35.85 \pm 0.96$ & 0.999 & 98.1 \\
CBS 171.28 & $5440-0.54$ & $23.79 \pm 0.12-36.55 \pm 0.14$ & 0.995 & 100.5 \\
CBS 171.28 ${ }^{\mathrm{b}}$ & & $23.86 \pm 0.10-36.22 \pm 0.06$ & 0.997 & 106.0 \\
MCR 320 & $2620-0.26$ & $15.89 \pm 0.09-29.28 \pm 0.21$ & 0.999 & 98.5 \\
MCR 320 ${ }^{\mathrm{b}}$ & & $15.88 \pm 0.07-29.45 \pm 0.13$ & 0.999 & 97.2 \\
\hline
\end{tabular}

a Fungal DNA was quantified by Qubit fluorometer in three independent measurements; ${ }^{\mathrm{b}}$ Diluted in the presence of $30 \mathrm{ng}$ of background wheat DNA.

Table 2. Results of the quantity median (IQR) and quantity mean of seven low concentrations of $F$. culmorum DNA (in picograms) analyzed in the presence of $30 \mathrm{ng}$ of wheat DNA.

\begin{tabular}{cccc}
\hline Amount of Input Template (pg) & $\begin{array}{c}\text { No. of Positive } \\
\text { Amplifications }\end{array}$ & Quantity Mean (pg) & $\begin{array}{c}\text { Quantity Median } \\
\text { (IQR) (pg) }\end{array}$ \\
\hline 2 & $72 / 72$ & $2.218(1.821-2.94)$ & 2.191 \\
0.5 & $72 / 72$ & $0.489(0.39-0.62)$ & 0.483 \\
0.2 & $72 / 72$ & $0.228(0.161-0.578)$ & 0.22 \\
0.05 & $72 / 72$ & $0.053(0.031-0.11)$ & 0.052 \\
0.02 & $72 / 72$ & $0.014(0.001-0.064)$ & 0.011 \\
0.01 & $72 / 72$ & $0.011(0.002-0.035)$ & 0.010 \\
0.005 & $47 / 72$ & $0.008(0.001-0.084)$ & 0.004 \\
30 ng of wheat background DNA only & $0 / 96$ & - & - \\
No template & $0 / 96$ & - & - \\
\hline
\end{tabular}




\subsection{The Quantification of F. culmorum DNA from Naturally Contaminated Grain Samples}

The FcMito assay was used to quantify F. culmorum DNA from 108 grain samples (Table S2). The presence of F. culmorum was revealed in all of them. The obtained $C_{\mathrm{T}}$ values ranged from 21.46 to 36.94 , while the estimated fungal DNA amount differed significantly between samples, ranging from 61.969 to $0.002 \mathrm{pg}$. However, most of the grain samples $(n=78)$ contained a very low amount of F. culmorum DNA $(<1 \mathrm{pg})$. Grain samples were additionally examined with the real-time PCR assay, which targeted the nuclear genome of F. culmorum [30]. Negative results were obtained for 60 samples. All of these samples contained very low amounts of F. culmorum, ranging from 1.753 to $0.002 \mathrm{pg}$, as quantified with the FcMito assay. Thus, over half of the amount of the samples analyzed with a nuclear-based assay produced false-negative results.

The DNA from F. graminearum s.s. was found in almost half of the samples $(n=53)$. Interestingly, in most samples exhibiting increased levels of F. graminearum s.s., a very low quantity of F. culmorum was revealed.

The grain samples were then analyzed for the presence of trichothecenes. Deoxynivalenol was the dominant trichothecene compound (Table S2). Mycotoxins were found in all samples except for two. To determine the existence of the relationship in the total trichothecenes and the DNA quantity in grain samples, Spearman's rank correlation was calculated separately for F. culmorum, F. graminearum s.s., and both species together. Spearman's rank correlation was used because non-normal distribution of the data. In all three cases, statistical analysis revealed positive correlations between the fungal DNA and the total trichothecene content $(r=0.36, r=0.35, r=0.49$, accordingly, $p<0.001)$.

\section{Discussion}

There are two major Fusarium species responsible for FHB in Europe: F. culmorum and F. graminearum s.s. Reliable identification and quantification of these species forms the basis of all studies related to population dynamics, fungal ecology, toxicology, and the efficacy of crop protection measures. Nowadays, qPCR is one of the most promising tools for quantification of Fusaria from environmental samples. However, the quantification of fungal DNA can often be hampered by the relatively low levels of fungal loads in environmental samples and the structure of the fungal cell wall-making disruption for nucleic acid extraction difficult [34]. It is possible to improve the sensitivity of fungal quantification by diagnostic assays targeting mtDNA. Considering the relatively small differences for mean and median of quantified DNA for 0.01 and $0.02 \mathrm{pg}$ (Table 2), the limit of quantification (LOQ) of the FcMito assay was determined as $0.05 \mathrm{pg}$. This is 18 -fold lower than LOQ of another F. culmorum specific TaqMan assay targeting the nuclear genome [30]. It was shown that the FcMito assay could detect $0.005 \mathrm{pg}$ of the input template, but only with a $35 \%$ false-negative rate. Thus, the limit of detection (LOD) of the designed assay could be determined between 0.05 and $0.005 \mathrm{pg}$. The haploid cell of F. culmorum contains $42 \mathrm{Mb}$ [36], which equals $0.04 \mathrm{pg}$. Therefore, LOQ of the FcMito assay $(0.05 \mathrm{pg})$ is equal to approximately one and a quarter of the haploid cell of F. culmorum. A comparison of the LOQ values of both FcMito and FgMito assays shows a 4-fold lower LOQ of FcMito than the FgMito assay. This can be explained by incorporation of a primer with an additional mismatch in the 3rd last nucleotide from the $3^{\prime}$ end of the FgMito assay. Although this modification increased the specificity of the assay [35], it negatively affected the LOQ and LOD of the FgMito assay (data not shown).

Atoui et al. [37] claimed that the best way to identify grain contamination by fungi is targeting the mycotoxigenic genes specifically where a particular mycotoxin can be produced by a number of species. However, it is occasionally impossible to distinguish a particular species. Atoui et al. [37] found that primers targeting the PKS13 gene involved in zearalenone (ZEA) biosynthesis detected F. graminearum s.s. and F. culmorum. A similar assay was developed by Meng et al. [38] and was specific for the zearalenone-producing F. graminearum s.s., F. culmorum, and F. cerealis. FcMito assay is species-specific, as it only amplifies the F. culmorum DNA (Table S1). 
In this study, high efficiency (98.5-100.5\%) and high coefficients of determination (over $\left.\mathrm{R}^{2}=0.995\right)$ were acquired for a series dilution of pure strain standards. Moreover, there were no significant differences in amplification profiles between pure strain standards and standards mixed with $30 \mathrm{ng}$ of wheat background DNA. This indicates that, since wheat DNA had no impact on FcMito assay, it can be successfully used in field sample analysis.

This study found a positive correlation between the F. culmorum DNA and the total trichothecenes present in naturally contaminated grains. Despite Spearman's rank correlation coefficient $(r=0.34)$ not being high, it was still significant. Similar results were obtained when correlating quantities of F. graminearum s.s. DNA to trichothecenes [35]. However, we found that correlation of the sum of trichothecenes to the sum of F. culmorum and F. graminearum s.s. DNA resulted in an increase in Spearman's rank correlation coefficient $(\mathrm{r}=0.49)$, which indicates that a more reliable prediction of trichothecene content in the grain requires quantification of both species. This also confirmed that both F. culmorum and F. graminearum s.s. are responsible for the current contamination of European grains with type B trichothecenes [24].

Fusaria differ significantly in pathogenicity, toxigenicity, and sensitivity to commonly used fungicides. Identification and quantification of predominant species is important in preventing and controlling the FHB epidemic. Furthermore, the quantification of fungal DNA can indicate plausible mycotoxin contamination. This may help in the prediction of potential toxicological risks. Due to its extremely high sensitivity, a FcMito assay may be used to study infection strategy of the pathogen in biomass-limited samples such as individual floral organs of cereals. Together with other mitochondrial-based assays, the assay developed in this study could be applied to reveal tissue-specific infection patterns in naturally infected caryopses, paleas, lemmas, and glumes on which compound appressoria are formed at initial stages of the infection process [39]. Our assay may also be used to characterize fungal concentrations in environmental samples with relatively lower amounts of fungal biomass such as air dust, soil, and water, without the need to cultivate fungi on artificial media. Finally, the mitochondrially based assay developed in this study would be valuable in many plant-breeding programs, as well as an initial step in food and feed quality assessment.

\section{Materials and Methods}

\subsection{Fungal Strains}

Table S1 lists the 138 Fusarium strains used in the specificity test. Polish isolates of F. culmorum [40] are kept in the Department of Phytopathology and Molecular Mycology of the University of Technology and Life Sciences (Bydgoszcz, Poland). The DBNP strains are located in the Department of Microbiology and Mycology of the University of Warmia and Mazury in Olsztyn (Olsztyn, Poland). The tested CBS strains are held in the Westerdijk Fungal Biodiversity Institute (Utrecht, The Netherlands). The strains from Italy and Luxemburg are kept in the Fungal Culture Collection of the Department Environmental Research and Innovation of the Luxembourg Institute of Science and Technology and are accessible at www.luxmcc.lu [41]. The Fusarium isolates were maintained at $25^{\circ} \mathrm{C}$ on a potato dextrose agar (PDA) before DNA extraction was conducted.

\subsection{Grain Samples}

The 108 grain samples were analyzed in the study presented in this paper (Table S2). The wheat samples from Luxembourg $(n=13)$ (received from the Luxembourg Institute of Science and Technology) were collected in 2007 and 2008 [42]. Polish samples were harvested in 2011 and 2012. An IKA A10 analytical grinding mill (IKA Werke GmbH \& Co. KG, Staufen im Breisgau, Germany) was used to initially grind $100 \mathrm{~g}$ of grain from each sample. Samples were kept at $-25^{\circ} \mathrm{C}$. 


\subsection{DNA Extraction}

The DNA extraction involved $0.1 \mathrm{~g}$ of mycelium collected from the top of PDA plates as well as $0.25 \mathrm{~g}$ of ground grain per sample. These samples were homogenized twice ( $30 \mathrm{~s}$ at a speed of $6.0 \mathrm{~m} / \mathrm{s}$ ) using a FastPrep-24 instrument (MP Biomedicals, Solon, OH, USA). A ChargeSwitch ${ }^{\circledR}$ gDNA Plant Kit (Invitrogen, Carlsbad, CA, USA) was used to isolate genomic DNA following the manufacturer's protocol. A Qubit ${ }^{\circledR}$ 2.0 Fluorometer and a Qubit ${ }^{\circledR}$ dsDNA BR Assay (Invitrogen, Carlsbad, CA, USA) were used to determine fungal and plant DNA concentrations according to the manufacturer's recommendations.

\subsection{Design of a Primer/Probe Set Specific for F. culmorum}

To find the polymorphic site to design a primer/probe set specific for F. culmorum, complete mitogenomes of F. culmorum (GenBank: NC_026993.1), F. graminearum s.s. (GenBank: NC_009493.1, DQ364632.1, KR011238.1, KP966561.1, KP966560.1, KP966559.1, KP966558.1, KP966557.1, KP966556.1, KP966555.1, KP966554.1, KP966553.1, KP966552.1, KP966551.1, KP966550.1) and F. gerlachii (GenBank: KM486533) were aligned. The sequence analysis revealed that the COX2 intron3 (3358 bp, 34.300-37.658) was present in F. culmorum only, which was then used to design primers and probe (Table 3) using the PRIMER EXPRESS 3.0 software package (Applied Biosystems, Foster City, CA, USA). The probe included a minor groove binder (MGB) moiety at the $3^{\prime}$ was labeled with 6-carboxyfluorescein (FAM) at the $5^{\prime}$-end. The probes were obtained from the ABI PRISM Primers and TaqMan Probe Synthesis Service and the primers were synthesized by Sigma-Aldrich (St. Louis, $\mathrm{MO}, \mathrm{USA})$.

Table 3. Primers and MGB probe developed for quantification of F. culmorum.

\begin{tabular}{cc}
\hline Primer/Probe Name & Primer/TagMan Probe Sequence \\
\hline COX2_1 & TCGTTGACGGTGAGGGTTGT \\
COX2_2 & GACTCGAACACGTCAACCAACTT \\
COX2 probe & FAM-CGGTTATTATTTCGAAAAGT-MGB \\
\hline
\end{tabular}

\subsection{Optimization of a TaqMan Assay Specific for F. culmorum}

The TaqMan reaction was performed according to Kulik et al. [35] in a 7500 Fast Real-Time PCR System (Applied Biosystems, Carlsbad, CA, USA). The optimized TaqMan assay specificity was verified by testing a total of 138 fungal strains (Table S1). The efficiency and sensitivity of the assay were determined using a ten-fold serial dilution of various amounts of gDNA (in picograms) of six F. culmorum strains as a template (Table 1). The background DNA impact was considered by testing the efficiency and sensitivity of the assay in the presence of $30 \mathrm{ng}$ of wheat DNA. Four replicates of each dilution were prepared for each TaqMan experiment. Two non-template controls (NTCs) were used: water-only and background DNA-only samples. The reaction efficiency and coefficient of determination $\left(\mathrm{R}^{2}\right)$ were calculated with the obtained $\mathrm{C}_{\mathrm{T}}$-values. The TaqMan reaction was performed in 96 replicates, using $30 \mathrm{ng}$ of wheat DNA as a template in order to verify the false-positive rate. To identify false-negative results, seven low concentrations of F. culmorum DNA $(2,0.5,0.2,0.05,0.02$, 0.01 , and $0.005 \mathrm{pg}$ ) were analyzed in the presence of $30 \mathrm{ng}$ of wheat DNA (Table 2). The concentration of each template was then analyzed in 72 replicates.

\subsection{Quantification of F. culmorum DNA from Naturally Contaminated Grain Samples}

Plant Internal Positive Control (pIPC) was used for normalization the DNA samples extracted from grains, according to Kulik et al. [43]. Subsequently, all samples were analyzed for the presence and quantity of F. culmorum using the FcMito assay. The amount of F. culmorum DNA (pg) was evaluated from $C_{T}$ values using a standard curve. All template concentrations were analyzed in three replicates under the conditions described previously. The obtained results were compared with the 
results of F. culmorum and F. graminearum s.s. quantification from a previous study by Kulik et al. [35]. Differences in sensitivity between the FcMito assay and nuclear-based assay [30] were revealed by comparing the $\mathrm{C}_{\mathrm{T}}$ values of both assays.

\subsection{Trichothecene Determination from the Grain Samples}

The levels of DON, 3ADON, 15ADON, and NIV were determined in grain samples. The Polish samples were analyzed for trichothecene presence according to the protocol described by Perkowski et al. [44], while samples from Luxembourg were analyzed according to Giraud et al. [42].

\subsection{Statistical Analyses}

Statistical analyses were conducted using STATISTICA (Data Analysis Software System, ver. 12.5; StatSoft Inc., Tulsa, OK, USA, 2014). The relationship between the DNA quantity and the total trichothecene content in grain samples $(p<0.05)$ was established by Spearman's rank correlation. The mean (pg) and median (IQR) (pg) quantities of seven low concentrations of the template $(2,0.5,0.2$, $0.05,0.02,0.01$, and $0.005 \mathrm{pg}$ ) analyzed in the presence of background wheat DNA were determined.

Supplementary Materials: The following are available online at http:/ / www.mdpi.com/2072-6651/10/5/211/s1. Table S1: List of fungal strains used for specificity testing of FcMito qPCR assay. Table S2: Results of quantification of F. culmorum and F. graminearum s.s. DNA from cereals with defined levels of trichothecenes using three different TaqMan assays.

Author Contributions: Conceptualization, K.B., T.K.; Formal analysis, D.Z.; Funding acquisition, T.K.; Investigation, K.B., T.K., A.O.-K., M.Bu., M.P., M.Be., A.B.-C., M.J., D.Z., K.T., J.D., J.P.; Methodology, K.B., T.K.; Project administration, K.B., T.K.; Resources, T.K., M.P., M.Be., A.B.-C., K.T.; Supervision, T.K.; Validation, K.B., T.K., A.O.-K., M.Bu., M.P., M.Be., A.B.-C., M.J., D.Z., K.T., J.D., J.P.; Writing - original draft, K.B., T.K., M.Be..

Funding: This research was funded by National Science Center, Poland, grant number 2015/19/B/NZ9/01329.

Acknowledgments: We thank the anonymous reviewer whose suggestions greatly increased the quality of this manuscript.

Conflicts of Interest: The authors declare no conflict of interest. The founding sponsors had no role in the design of the study; in the collection, analyses, or interpretation of data; in the writing of the manuscript; or in the decision to publish the results.

\section{References}

1. Scherm, B.; Balmas, V.; Spanu, F.; Pani, G.; Delogu, G.; Pasquali, M.; Migheli, Q. Fusarium culmorum: Causal agent of foot and root rot and head blight on wheat. Mol. Plant Pathol. 2013, 14, 323-341. [CrossRef] [PubMed]

2. Oldenburg, E.; Ellner, F. Distribution of disease symptoms and mycotoxins in maize ears infected by Fusarium culmorum and Fusarium graminearum. Mycotoxin Res. 2015, 31, 117-126. [CrossRef] [PubMed]

3. Nganje, W.E.; Kaitibie, S.; Wilson, W.W.; Leistritz, F.L.; Bangsund, D.A. Economic Impacts of Fusarium Head Blight in Wheat and Barley: 1993-2001. Agribus. Appl. Econ. Rep. 2004, 538, 1-53.

4. Desjardins, A.E. Fusarium Mycotoxins Chemistry. Genetics and Biology; American Phytopathological Society Press: St. Paul. MN, USA, 2006.

5. Zain, M.E. Impact of mycotoxins on humans and animals. J. Saudi Chem. Soc. 2011, 15, 129-144. [CrossRef]

6. Marin, S.; Ramos, A.J.; Cano-Sancho, G.; Sanchis, V. Mycotoxins: Occurrence, toxicology, and exposure assessment. Food Chem. Toxicol. 2013, 60, 218-237. [CrossRef] [PubMed]

7. Pasquali, M.; Migheli, Q. Genetic approaches to chemotype determination in type B- trichothecene producing Fusaria. Int. J. Food Microbiol. 2014, 189, 164-182. [CrossRef] [PubMed]

8. Drakulic, J.; Kahar, M.H.; Ajigboye, O.; Bruce, T.; Ray, R.V. Contrasting Roles of Deoxynivalenol and Nivalenol in Host-Mediated Interactions between Fusarium graminearum and Sitobion avenae. Toxins 2016, 8, 353. [CrossRef] [PubMed]

9. Pasquali, M.; Spanu, F.; Scherm, B.; Balmas, V.; Hoffmann, L.; Hammond-Kosack, K.E.; Beyer, M.; Migheli, Q. FcStuA from Fusarium culmorum controls wheat foot and root rot in a toxin dispensable manner. PLoS ONE 2013, 8, e57429. [CrossRef] [PubMed] 
10. Parry, D.W.; Jenkinson, P.; McLeod, L. Fusarium ear blight (scab) in small grain cereals-A review. Plant Pathol. 1995, 44, 207-238. [CrossRef]

11. Van der Lee, T.; Zhang, H.; van Diepeningen, A.; Waalwijk, C. Biogeography of Fusarium graminearum species complex and chemotypes: A review. Food Addit. Contam. Part A 2015, 32, 453-460. [CrossRef] [PubMed]

12. Lysøe, E.; Seong, K.Y.; Kistler, H.C. The transcriptome of Fusarium graminearum during the infection of wheat. Mol. Plant-Microbe Interact. 2011, 24, 995-1000. [CrossRef] [PubMed]

13. Raffaele, S.; Kamoun, S. Genome evolution in filamentous plant pathogens: Why bigger can be better. Nat. Rev. Microbiol. 2012, 10, 417-430. [CrossRef] [PubMed]

14. Waalwijk, C.; Kastelein, P.; De Vries, I.; Kerényi, Z.; Van Der Lee, T.; Hesselink, T.; Köhl, J.; Kema, G. Major changes in Fusarium spp. in wheat in the Netherlands. Eur. J. Plant Pathol. 2003, 109, 743-754. [CrossRef]

15. Jennings, P.; Coates, M.E.; Turner, J.A.; Chandler, E.A.; Nicholson, P. Determination of deoxynivalenol and nivalenol chemotypes of Fusarium culmorum isolates from England and Wales by PCR assay. Plant Pathol. 2004, 53, 182-190. [CrossRef]

16. Xu, X.M.; Parry, D.W.; Nicholson, P.; Thomsett, M.A.; Simpson, D.; Edwards, S.G.; Cooke, B.M.; Doohan, F.M.; Brennan, J.M.; Moretti, A.; et al. Predominance and association of pathogenic fungi causing Fusarium ear blight in wheat in four European countries. Eur. J. Plant Pathol. 2005, 112, 143-154. [CrossRef]

17. Beyer, M.; Pogoda, F.; Pallez, M.; Lazic, J.; Hoffmann, L.; Pasquali, M. Evidence for a reversible drought induced shift in the species composition of mycotoxin producing Fusarium head blight pathogens isolated from symptomatic wheat heads. Int. J. Food Microbiol. 2014, 182-183, 51-56. [CrossRef] [PubMed]

18. Kammoun, L.G.; Gargouri, S.; Hajlaoui, M.R.; Marrakchi, M. Occurrence and Distribution of Microdochium and Fusarium Species Isolated from Durum Wheat in Northern Tunisia and Detection of Mycotoxins in Naturally Infested Grain. J. Phytopathol. 2009, 157, 546-551. [CrossRef]

19. Kammoun, L.G.; Gargouri, S.; Barreau, C.; Richard-Forget, F.; Hajlaoui, M.R. Trichothecene chemotypes of Fusarium culmorum infecting wheat in Tunisia. Int. J. Food Microbiol. 2010, 140, 84-89. [CrossRef] [PubMed]

20. Pancaldi, D.; Tonti, S.; Prodi, A.; Salomoni, D.; Dal Prà, M.; Nipoti, P.; Alberti, I.; Pisi, A. Survey of the main causal agents of Fusarium head blight of durum wheat around Bologna, northern Italy. Phytopathol. Mediterr. 2010, 49, 258-266. [CrossRef]

21. Fakhfakh, M.M.; Yahyaoui, A.; Rezgui, S.; Elias, E.M.; Daaloul, A. Identification and pathogenicity assessment of Fusarium spp. sampled from durum wheat fields in Tunisia. Afr. J. Biotechnol. 2011, 10, 6529-6539.

22. Balmas, V.; Scherm, B.; Marcello, A.; Beyer, M.; Hoffmann, L.; Migheli, Q.; Pasquali, M. Fusarium species and chemotypes associated with Fusarium head blight and Fusarium root rot on wheat in Sardinia. Plant Pathol. 2015, 64, 972-979. [CrossRef]

23. Yekkour, A.; Toumatia, O.; Meklat, A.; Verheecke, C.; Sabaou, N.; Zitouni, A.; Mathieu, F. Deoxynivalenolproducing ability of Fusarium culmorum strains and their impact on infecting barley in Algeria. World J. Microbiol. Biotechnol. 2015, 31, 875-881. [CrossRef] [PubMed]

24. Pasquali, M.; Beyer, M.; Logrieco, A.; Audenaert, K.; Balmas, V.; Basler, R.; Boutigny, A.L.; Chrpová, J.; Czembor, E.; Gagkaeva, T.; et al. A European Database of Fusarium graminearum and F. culmorum Trichothecene Genotypes. Front. Microbiol. 2016, 7, 406. [CrossRef] [PubMed]

25. Laraba, I.; Boureghda, H.; Abdallah, N.; Bouaicha, O.; Obanor, F.; Moretti, A.; Geiser, D.M.; Kim, H.-S.; McCormick, S.P.; Proctor, R.H.; et al. Population genetic structure and mycotoxin potential of the wheat crown rot and head blight pathogen Fusarium culmorum in Algeria. Fungal Genet. Biol. 2017, 103, $34-41$. [CrossRef] [PubMed]

26. Dubos, T.; Pogoda, F.; Ronellenfitsch, F.K.; Junk, J.; Hoffmann, L.; Beyer, M. Fractal dimension and shape parameters of asexual Fusarium spores from selected species: Which species can be distinguished? J. Plant Dis. Prot. 2012, 119, 8-14. [CrossRef]

27. Gong, L.; Jiang, Y.; Chen, F. Molecular strategies for detection and quantification of mycotoxin-producing Fusarium species: A review. J. Sci. Food. Agric. 2015, 95, 1767-1776. [CrossRef] [PubMed]

28. Pitt, J.I. The significance of potentially toxigenic fungi in food. Food Aust. 1984, 36, 218-219.

29. Taniwaki, M.H. An update on ochratoxigenic fungi and ochratoxin A in coffee. In Advances in Food Mycology; Hocking, A.D., Pitt, J.I., Samson, R.A., Thrane, U., Eds.; Springer: Boston, MA, USA, 2006; pp. 189-202.

30. Waalwijk, C.; van der Heide, R.; de Vries, I.; van der Lee, T.; Schoen, C.; Corainville, G.C.; Häuser-Hahn, I.; Kastelein, P.; Köhl, J.; Lonnet, P.; et al. Quantitative detection of Fusarium species in wheat using TaqMan. Eur. J. Plant Pathol. 2004, 110, 481-494. [CrossRef] 
31. Leišová, L.; Kučera, L.; Chrpová, J.; Sýkorová, S.; Šíp, V.; Ovesná, J. Quantification of Fusarium culmorum in Wheat and Barley Tissues Using Real-Time PCR in Comparison with DON Content. J. Phytopathol. 2006, 154, 603-611. [CrossRef]

32. Moradi, M.; Oerke, E.-C.; Steiner, U.; Tesfaye, D.; Schellander, K.; Dehne, H.-W. Microbiological and SYBR M Green Real-Time PCR Detection of Major Fusarium Head Blight Pathogens on Wheat Ears. Microbiology 2010, 79, 655-663. [CrossRef] [PubMed]

33. Sanoubar, R.; Bauer, A.; Seigner, L. Detection, Identification and Quantification of Fusarium graminearum and Fusarium culmorum in Wheat Kernels by PCR Techniques. J. Plant Pathol. Microb. 2015, 6, 287. [CrossRef]

34. Leite, G.M.; Magan, N.; Medina, Á. Comparison of different bead-beating RNA extraction strategies: An optimized method for filamentous fungi. J. Microbiol. Methods 2012, 88, 413-418. [CrossRef] [PubMed]

35. Kulik, T.; Ostrowska, A.; Buśko, M.; Pasquali, M.; Beyer, M.; Stenglein, S.; Załuski, D.; Sawicki, J.; Treder, K.; Perkowski, J. Development of an FgMito assay: A highly sensitive mitochondrial based qPCR assay for quantification of Fusarium graminearum sensu stricto. Int. J. Food Microbiol. 2015, 210, 16-23. [CrossRef] [PubMed]

36. Urban, M.; King, R.; Andongabo, A.; Maheswari, U.; Pedro, H.; Kersey, P.; Hammond-Kosack, K. First draft genome sequence of a UK strain (UK99) of Fusarium culmorum. Genome Announc. 2016, 4, e00771-16. [CrossRef] [PubMed]

37. Atoui, A.; El Khoury, A.; Kallassy, M.; Lebrihi, A. Quantification of Fusarium graminearum and Fusarium culmorum by real-time PCR system and zearalenone assessment in maize. Int. J. Food Microbiol. 2012, 154, 59-65. [CrossRef] [PubMed]

38. Meng, K.; Wang, Y.; Yang, P.; Luo, H.; Bai, Y.; Shi, P.; Yuan, T.; Ma, R.; Yao, B. Rapid detection and quantification of zearalenone-producing Fusarium species by targeting the zearalenone synthase gene PKS4. Food Control 2010, 21, 207-211. [CrossRef]

39. Boenisch, M.J.; Schäfer, W. Fusarium graminearum forms mycotoxin producing infection structures on wheat. BMC Plant Biol. 2011, 11, 110. [CrossRef] [PubMed]

40. Baturo-Cieśniewska, A.; Suchorzyńska, M. Verification of the effectiveness of SCAR (sequence characterized amplified region) primers for the identification of Polish strains of Fusarium culmorum and their potential ability to produce B-trichothecenes and zearalenone. Int. J. Food Microbiol. 2011, 148, 168-176. [CrossRef] [PubMed]

41. Piec, J.; Pallez, M.; Beyer, M.; Vogelgsang, S.; Hoffmann, L.; Pasquali, M. The Luxembourg database of trichothecene type B F. graminearum and F. culmorum producers. Bioinformation 2016, 12, 1-3. [CrossRef] [PubMed]

42. Giraud, F.; Pasquali, M.; Jarroudi, M.; Vrancken, C.; Brochot, C.; Cocco, E.; Hoffmann, L.; Delfosse, P.; Bohn, T. Fusarium head blight and associated mycotoxin occurrence on winter wheat in Luxembourg in 2007/2008. Food Addit. Contam. Part A 2010, 27, 825-835. [CrossRef] [PubMed]

43. Kulik, T.; Treder, K.; Załuski, D. Quantification of Alternaria, Cladosporium, Fusarium and P. verrucosum in conventional and organic grains by qPCR. J. Phytopathol. 2014, 163, 522-528. [CrossRef]

44. Perkowski, J.; Kiecana, I.; Kaczmarek, Z. Natural occurrence and distribution of Fusarium toxins in contaminated barley cultivars. Eur. J. Plant Pathol. 2003, 109, 331-339. [CrossRef]

(C) 2018 by the authors. Licensee MDPI, Basel, Switzerland. This article is an open access article distributed under the terms and conditions of the Creative Commons Attribution (CC BY) license (http://creativecommons.org/licenses/by/4.0/). 